International Journal of Life Sciences
Available online at http://sciencescholar.us/journal/index.php/ijls
Vol. 3 No. 3, December 2019, pages: $25 \sim 31$
e-ISSN: 2550-6986, p-ISSN: 2550-6994
https://doi.org/10.29332/ijls.v3n3.364

\title{
Environmental Impact of Energy Production with Generators
}

\author{
CrossMark \\ Yoan Pablo Rodríguez Monier a, Rodolfo Vila Feijoo b ${ }^{\text {, }}$ Kenichi Gasbar Garcia Alvarez c, \\ Majela Prieto Betancourt ${ }^{\mathrm{d}}$
}

Article history: Received 09 May 2019, Accepted: 31 August 2019, Published: 23 November 2019

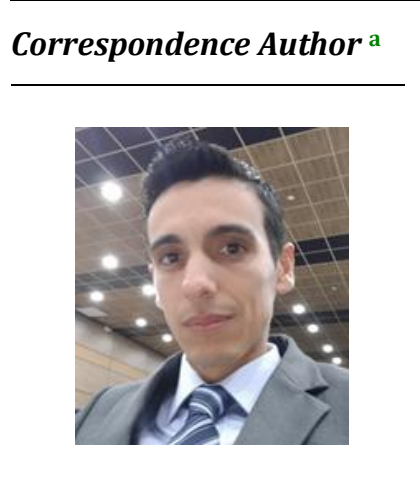

\section{Keywords}

diesel pollution;

energy;

environment;

noise;

pollution;

\begin{abstract}
The generation of energy with fossil fuels, is one of the actions that currently affects the environment on the planet, The pollution that occurs in the generation processes causes traces that take many years to disappear, currently only the appropriate environmental management systems can control these effects by taking measures that can be educational, training and dissemination activities only a Global effort will help mitigate the negative effects caused in power generation. Energy is necessary for the continuity of development, which means that. At present, environmental pollution seems to have become an inevitable element and something that every modern society must pay if it does not want to give up its comforts, therefore in the process of introducing new technologies in energy generation must take measures that mitigate these negative impacts, valuing their magnitude and ways to proper gestate.
\end{abstract}

e-ISSN: 2550-6986, p-ISSN: 2550-6994@ Copyright 2019. The Author. SS Journals Published by Universidad Técnica de Manabí. This is an open-access article under the CC BY-SA 4.0 license (https://creativecommons.org/licenses/by-sa/4.0/) All rights reserved.

\section{Contents}

Abstract

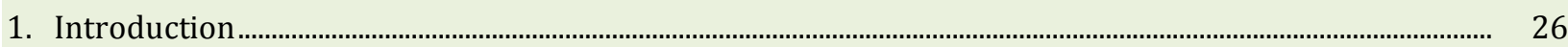

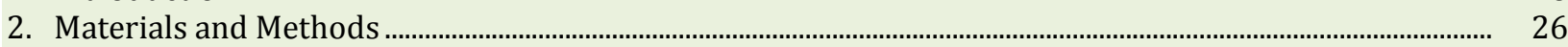

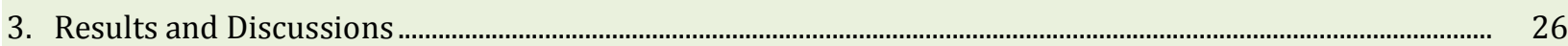

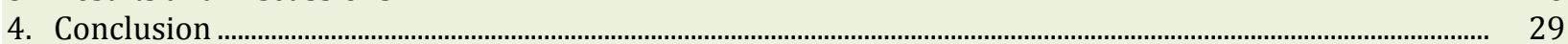

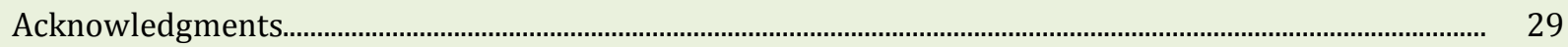

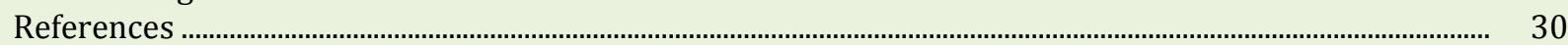

Biography of Authors ............................................................................................................................................ 31

a Unidad Educativa Capitan Geovanni Calles, El Coca, Orellana, Ecuador

b Escuela de Educación Basica Gustavo Lara, El Coca, Orellana, Ecuador

c Unidad Educativa Capitan Geovanni Calles, El Coca, Orellana, Ecuador

d Unidad Educativa Francisco de Orellana, El Coca, Orellana, Ecuador 


\section{Introduction}

The generation of energy with generators is important because of the vitality of energy in social sites of interest in many countries, currently they are extended to Latin American countries, you can not think of electricity generation if you do not take the same pace to The Environment, these must go together, it is necessary to move in the direction of achieving greater integration between life forms, material development, with environmental interests (Hourne et al., 2012).

Throughout the nineteenth and twentieth centuries, along with the technological development achieved, human activity has transformed the chemical composition of water and air on Earth, has modified the face of the planet itself and has altered life itself. The availability and capacity of use of the energy produced with conventional fuels have achieved that humanity has increased the volumes of production and consumption. Human activity has produced effects and alterations in natural systems, some positive others negative, some reversible others irreversible; some temporary and others permanent, some immediate others of long gestation and maturation; sometimes visible; but not easily detectable in most cases and often negligible, but often catastrophic (Romo \& Galina, 2008). Every year, the planet receives 99 million tons of Sulfur Oxide, 68 million tons of Nitrogen Oxide, 177 million tons of carbon monoxide and carbon dioxide, as well as millions of tons of toxic waste (Martínez et al., 2007; Arcentales et al., 2017).

Knowing how to live with energy development and a healthy environment is the challenge, which must have achieved. Being able to control the places where investments are made in power generation systems is of special importance for inventories of caused impacts, (positive or negative), the positives are directly linked to social welfare, the negatives are aimed at the environment, where the human being is the most affected, so he must seek innovative solutions that reduce these conditions.

\section{Materials and Methods}

An experimental investigation was carried out, to determine the noise caused by the generators and their impact on the environment, a professional sound level meter was used to measure the noise, as well as equipment for measuring distance. A bibliographic review was carried out, to know the other similar studies and to compare the results obtained, the deductive inductive method was used to arrive at the results presented.

\section{Results and Discussions}

Being able to control the places where investments are made in power generation systems is of special importance for inventories of caused impacts, (positive or negative), the positives are directly linked to social welfare, the negatives are aimed at the environment, where the human being is the most affected, so he must seek innovative solutions that reduce these conditions.

\section{Environmental impact of energy generation}

Pollution in systems that generate energy affects the atmosphere, soil, and water due to the impregnation, in these, of particles or products that affect human health, quality of life or the natural functioning of ecosystems, it can be controlled to an acceptable level only, if economic costs are not considered; However, economics is a very important factor in life, there are cases in which pollutants persist, however, the efforts made to eliminate them are great, but when an environmental culture is created in people who are linked to these generation processes, these costs decrease, having the clear awareness that "it is better to avoid than to decontaminate." (González et al., 2008; Gamez et al., 2016). 
Pollution of the atmosphere

Produced by waste or gaseous secondary products, solid or liquid, can endanger the health of human beings and cause damage to plants and animals, attack different materials, reduce visibility or produce unpleasant odors example of this we have those They are produced in the chimneys of many industries where carbon dioxide and sulfur are released, as are the old technologies used for transportation, many of them responsible for global warming, the sulfur dioxide that is the main cause of rain acid, this type of pollution can be found anywhere in the city, one of the sectors that pollutes the most is transportation, as well as energy production, industry, agriculture, biomass burning, and fossil fuel, not very far the individual actions of burning of different residuals in the areas close to the houses (Rojas, 2004; Gamez et al., 2017).

\section{Pollution of the atmosphere}

It can be observed from foreign matters as microorganisms, chemical products, industrial, domestic, urban, nuclear waste. This can be superficial or underground, it refers to the presence of contaminants' insufficient quality and time to cause adverse effects on human health and the environmental quality of the associated ecosystems. There are regulations that regulate the dumping of polluting waste with the objective of mitigating the conditions as a result of the inadequate application of agrochemicals to the earth's surface; infiltration into the ground of hazardous substances accidentally spilled or contained in leachates from landfills; improper location, etc.

Some of the effects of water pollution can be effects on aquatic ecosystems and loss of biological diversity, which can also affect the quality of life of man and wildlife as well as salinization processes and soil degradation. In the era of fossil fuels, the surface of the Earth has also undergone a remarkable transformation, the same substances that have polluted the air and water are often dormant in the soil, sometimes in dangerous concentrations that constitute a threat to the human health. Land degradation, loss of quality and quantity of soil can be due to several processes: erosion, salinization, pollution, drainage, acidification, lateralization. Land degradation is also linked to processes developed on a larger scale, such as desertification (Martinez et al., 2018; Chilán et al., 2018).

In the generator sets installed, the most frequent causes of contamination are caused by spills and spillage directly to the oilseed water with high fuel content, which may contain high concentrations of heavy metals. The contamination may also be due to other chemical wastes, by-products of generation processes, or dumping of hazardous waste such as waste oils and filters in inappropriate places and without the necessary conditions.

\section{Another of the environmental conditions that have caused by the generation of energy is noise pollution}

A term that refers to noise when it becomes an annoying sound that can produce physiological and psychological effects harmful to people, also affecting populations. The effects produced by noise can physiologically can because hearing loss or insomnia, or psychological disorders, such as exaggerated irritability (González \& Fernández, 2014).

The efficient start-up of the generator sets involves different activities, an adequate environmental management system where the proper location of the equipment, maintenance, effective deposition of the waste generated, protection of the operators and the work environment are integrated, preparation of personnel linked to these activities, in addition to education to nearby populations. The installation of the GE is added to the various measures that have been implemented to materialize this program, these are internal combustion engines that produce different types of contamination during operation.

Gas-phase hydrocarbons, carbon monoxide and dioxide, nitrogen monoxide and dioxide, sulfur dioxide, fine material in the form of elemental and organic carbon, sulfates, nitrates, metals, and other trace elements. Internal Combustion Engines (Diesel) act on the environment in various ways: Depleting non-renewable fossil fuel, consuming oxygen from the atmosphere, emitting and polluting the atmosphere, with toxic gases harmful to human health, flora and fauna contribute to the greenhouse effect, in addition to emitting high levels of noise.

Monier, YPR, Feijoo, RV, Alvarez, KGG, \& Betancourt, MP (2019). Environmental impact of energy production with generators. International Journal of Life Sciences , 3 (3), 25-31. https://doi.org/10.29332/ijls.v3n3.364 
Contamination of water by the Generators, they are observed when they are poured into a receiving body, substances that contribute to it a polluting load capable of changing its characteristics, being even possible that its capacity of self-purification is exceeded, causing severe and irreversible damage. The oils used by GEs are prone to water contamination, because due to spillage deposition. They can seep and contaminate the water table so that a previous treatment must be done and made independent of household waste, they must not go to the drains, neither in the field, in the sites it repurposes a system of treatment of the waters, with Zeolite that will allow filtering the rainwater and trawls of the used oils with the objective of mitigating these effects and preventing any type of affection to the environment

Soil contamination has caused by carelessness and spillage of residual oils, fuel, these can have avoided paying attention, and attention to the entire procedure indicated for this, we could suggest that pollution caused by spills in the soil very normal in some places, aspects negatives that can have mitigated with proper environmental education. The existence of spillage of any type of hazardous waste (oils or fuel) in the soil due to the technological process of the generators must take mitigation measures and create appropriate habits after dumping such as looking for absorbent substances such as sawdust and the zeolite.

\section{Noise pollution}

Causes harmful alterations Noise can indeed become an aggressive agent, and therefore it can be a factor in environmental pollution. When referring to noise pollution is more general, because it also includes the effect of ultrasound and infrasound, both inaudible to humans, but capable of causing harmful effects on man and the ecosystem (Fernández, 2011).

In the generator sets, noise is an unwanted sound because different noise intensities have perceived at different distances from the groups or batteries; this may or may not be harmful and has related to the position and location of the receivers. International Standards establishes the method of measuring the sound level used as an indicator of environmental noise together with possible forecast models and maximum permissible and tolerable levels inhabitable areas, both inside the home and in the surrounding urbanized areas. For technological reasons, the emerging groups have has installed in places where in some cases they cause environmental damage, some of the generator sets noise intensity measurements have been made in different directions and at different distances, figure 1 shows two examples of the measurements made.

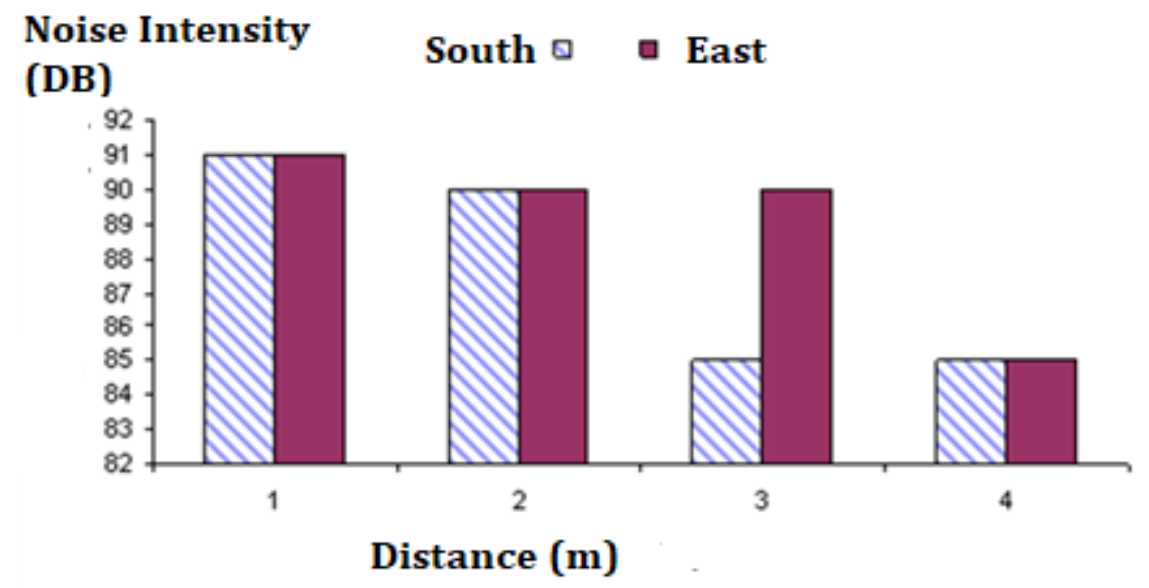

Figure 1. Measurements made in a distributed group

This installation is close to a population area as can be seen in the figure 4 meters away, the minimum permissible noise level has not yet been obtained according to (WHO) (Platzer et al., 2007), is close to 80 or 85 decibels, it also depends a lot on the direction of the air, as you can see there are different values for different cardinal points. In figure 2, the noise level of an Emergency Generator set located in a polyclinic is shown, as can. 
In figure 2, the noise level of an Emergency Generator set located in a polyclinic is shown, as can be seen for the same distance that has different values for different cardinal points.

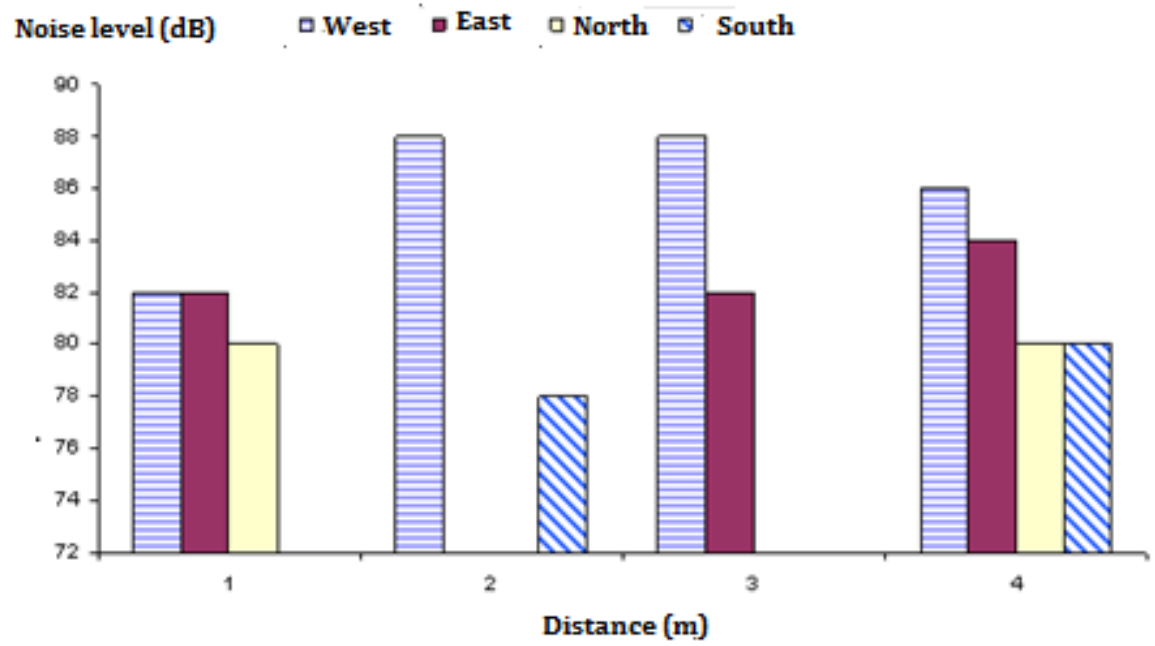

Figure 2. Noise level of the Emergency Generator set located in a polyclinic

As seen 2 meters away, the noise level is $78 \mathrm{~dB}$, value outside the allowable range, in these cases of emergency groups; the majority are located in prioritized objectives where there is affection to the nearby population. To reduce these effects, measures have been taken with workers and population close to the sites and work on investment proposal programs in places where populations are very close with the objective of creating sonic barriers that mitigate these negative effects, in addition to programs of afforestation that will reduce these negative effects by protecting the soil and improving air quality.

\section{Conclusion}

An analysis of the environmental impact and the mitigation measures of the negative effects caused by the introduction of the technology was made that, although they are systems that comply with all exhaust gas emission standards, there are negative conditions that must be controlled and that affect the environment.

\section{Acknowledgments}

The authors thank the editors of the magazine for allowing them to publish in it, thanks.

Monier, YPR, Feijoo, RV, Alvarez, KGG, \& Betancourt, MP (2019). Environmental impact of energy production with generators. International Journal of Life Sciences , 3 (3), 25-31. https://doi.org/10.29332/ijls.v3n3.364 


\section{References}

Arcentales, G. A. T., Gordin, R. G., Perez, A. V., \& Rodriguez, A. Z. (2017). Climatization, energy efficiency and environmental protection. International Research Journal of Engineering, IT \& Scientific Research, 3(2), 5966.

Chilán, J. C. H., Torres, S. G. P., Machuca, B. I. F., Cordova, A. J. T., Pérez, C. A. M., \& Gamez, M. R. (2018). Social impact of renewable energy sources in the province of Loja. International Journal of Physical Sciences and Engineering, 2(1), 13-25. https://doi.org/10.29332/ijpse.v2n1.79

Fernández, F. (2011). Estudio general de la contaminacion acustica en las ciudades de andalucia. Cuadernos Geográficos(49), 55-92. Obtenido de https://www.redalyc.org/pdf/171/17122051003.pdf

Gamez, M. R., Perez, A. V., Arauz, W. M. S., \& Jurado, W. C. C. (2016). Sustainable transformation of energy matrix. International Research Journal of Engineering, IT \& Scientific Research, 2(9), 37-43.

Gamez, MR, Perez, AV, Sera, AS, \& Ronquillo, ZM (2017). Renewable energy sources and local development. International Journal of Social Sciences and Humanities, $1(2), 10$ 19. https://doi.org/10.29332/ijssh.v1n2.31

González, I., Cervantes, O., Melchor, L., Medina, A., \& Cisnero, O. (2008). Gases y Ruido, dos contaminantes de los grupos electrogenos. (2), 56-65. Obtenido de https://www.redalyc.org/pdf/1813/181320254007.pdf

González, Y., \& Fernández, Y. (2014). Efectos de la contaminación sónica sobre la salud de estudiantes y docentes, en centros escolares. Revista Cubana de Higiene y Epidemiología, 52(3), 402-410. Obtenido de https://www.redalyc.org/pdf/2232/223240764012.pdf

Hourne, M., Brito, M., Castillo, A., Fraga, E., \& Diaz, A. (2012). Análisis de criticidad de grupos electrógenos de la tecnología fuel oil en Cuba. Revista Ciencias Técnicas Agropecuarias, 21(3), 55-61. Obtenido de http://scielo.sld.cu/pdf/rcta/v21n3/rcta09312.pdf

Martínez, M., Fernandez, A., Molina, E., \& García, R. (2007). Grupos electrogenos y su impacto ambiental. Higiene y Sanidad Ambiental, 7, 217-221. Obtenido de http://www.saludpublica.es/secciones/revista/revistaspdf/bc51015c2c43ce3_Hig.Sanid.Ambient.7.217-221(2007).pdf

Martinez, P., Martinez, L., Rodríguez, R., \& Martinez, R. (2018). Evaluación del sistema tratamiento de residuales líquidos generados en una central eléctrica operando con "fuel oil". Alternativas tecnológicas. Tecnología Química, 153-168. Obtenido de http://scielo.sld.cu/pdf/rtq/v38n1/rtq12118.pdf

Platzer, L., Rodrigo, C., Cevo, J., \& Ayala, F. (2007). Medición de los niveles de ruido ambiental en la ciudadde Santiago de Chile. Revista de Otorrinolaringología cirugia de cabeza y cuellos(67), 122-128. Obtenido de https://scielo.conicyt.cl/pdf/orl/v67n2/art05.pdf

Rojas, N. (2004). Revisión de las emisiones de material particulado por la combustión de diesel y biodiesel. Revista de Ingenieria(20), 58-62. Obtenido de http://www.scielo.org.co/pdf/ring/n20/n20a7.pdf

Romo, D., \& Galina, S. (2008). El futuro de los energéticosen la globalización. Análisis Económico, 23(54), 305327. Obtenido de https://www.redalyc.org/pdf/413/41311483015.pdf 
Biography of Authors

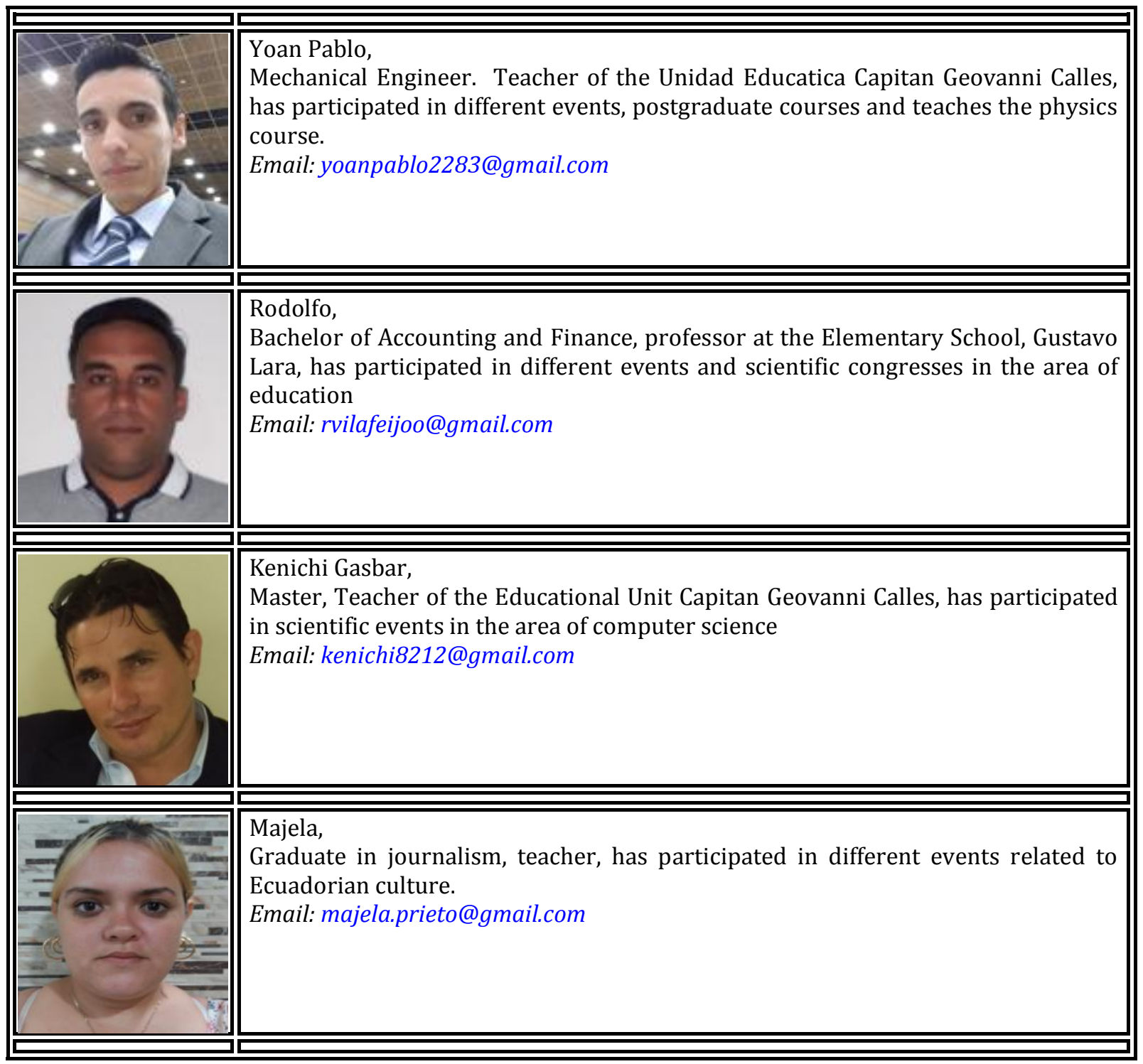

Monier, YPR, Feijoo, RV, Alvarez, KGG, \& Betancourt, MP (2019). Environmental impact of energy production with generators. International Journal of Life Sciences , 3 (3), 25-31. https://doi.org/10.29332/ijls.v3n3.364 